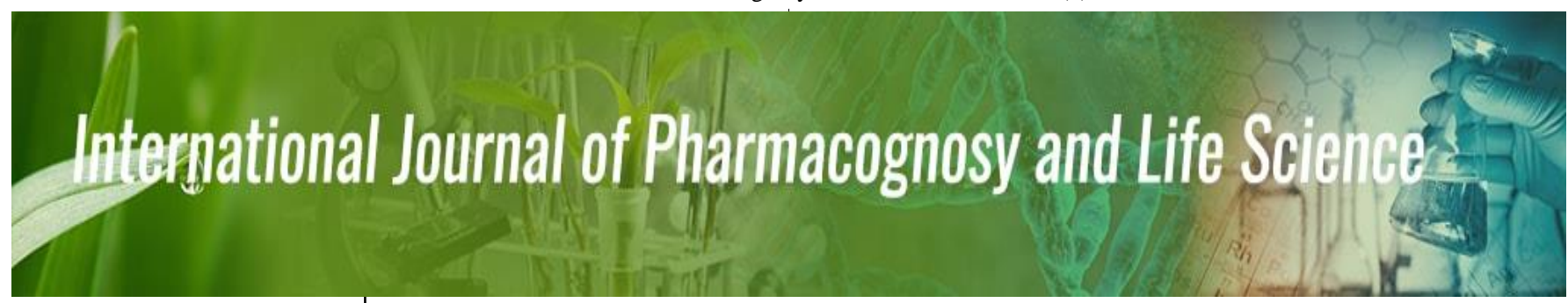

E-ISSN: 2707-2835

P-ISSN: 2707-2827

IJPLS 2020; 1(1): 51-54

Received: 22-11-2019

Accepted: 27-12-2019

Dr. Vishal Bharat Babar PG Research, Department of Pharmaceutical Chemistry, Dattakala College of Pharmacy, Swami-Chincholi, Tal: Daund, Dist. Pune, Maharashtra, India

Prajwala Rajkumar Khapale Department of Pharmacology and Toxicology, Dattakala College of Pharmacy, SwamiChincholi, Tal: Daund, Dist: Pune, Maharashtra, India

Sudarshan Narayan Nagarale Department of Pharmacology and Toxicology, Dattakala College of Pharmacy, SwamiChincholi, Tal: Daund, Dist: Pune, Maharashtra, India
Corresponding Author: Dr. Vishal Bharat Babar PG Research, Department of Pharmaceutical Chemistry, Dattakala College of Pharmacy, Swami-Chincholi, Tal: Daund, Dist. Pune, Maharashtra, India

\section{Phytochemical investigation, antibacterial and anticancer activities of the extract of Momordica charantia}

\author{
Dr. Vishal Bharat Babar, Prajwala Rajkumar Khapale and Sudarshan \\ Narayan Nagarale
}

DOI: https://doi.org/10.33545/27072827.2020.v1.i1a.18

\begin{abstract}
Cancer cause sickness and consequently can be viably overwhelmed by a multi-constituently remedial strategy. Herbal extracts shows the example of such stratagem. However, less research have been carried out till date that portray the effect of different extraction techniques on the phyto compounds profile of plant extracts and its effect on anticancer activity. Momordica charantia is a member of the Cucurbitaceae. It is a popular vegetable harvest in Indian customary medicine since olden times. It has potential lipid lowering and antioxidant activity and antidiabetic. In the present study, we have evaluated the anticancer prospective of methanolic and acetone extracts of Momordica charantia (MCME) and (MCAE). Reported results show that (MCME) is rich in bioactive compounds shown anticancer activity with Cell lines of (IC50) with MCF 715.6 \pm 1.3 and HeLa $28.2 \pm 1$. This study based on the presence of cytotoxic from the Momordica charantia, which have been further used in herbal formulations study as an anticancer activity. Our conclusion support additional indepth study of this pharmacologic activity as a malignant tumour agent.
\end{abstract}

Keywords: Momordica Charantia, Malignant Tumour, Anticancer, Phytochemical, Antibacterial

\section{Introduction}

Cancer is a main reason of death worldwide, representing for $13 \%$ of all deaths worldwide in 2008 (WHO, 2013) ${ }^{[20]}$. At present in many developing nations, malignancy is the third foremost cause of death after contagious and cardiovascular diseases (Tanih, 2013) ${ }^{[16]}$. As indicated by the World Health Organisation, there may be 21.4 million instances of cancer and 13.2 million passing from cancer every year by 2030 (ACS, 2011). Genetically and molecular alteration such as invasion angiogenesis, transformation, deregulation of apoptosis, proliferation and metastasis are characteristics of cancer (Fimognari et al., 2011) ${ }^{[6]}$. Hence there is an urge for the expansion of new anticancer medicine for its treatment and prevention. Bioactive compounds from plants play a foremost taskin the discovery of such new drugs. It has been estimated that about $60 \%$ of approved drugs were of natural origin (Douglas Hanahan and Robert, 2000) ${ }^{[4]}$.

Medicinal plants are well considered in the fundamental sources of natural bioactive compounds. It has assessed that about $50 \%$ of the treatment products in United States of America and Europe countries are basically from products derived from natural or their relative derivatives (Newman et al., 2003) ${ }^{[9]}$. Beyond the 250,000-500,000 plant species in the earth, just $1-10 \%$ have been examined biologically and chemically for their potential pharmaceutical value (Verpoorte, 2000) ${ }^{[18]}$. The utilizing of complementary alternative medicine has dramatically increased in India along with USA, in the last 2 decades (Pandey et al., 2006) Approximately $60 \%$ of anticancer compounds are derived from medicinal plants and other natural resources; however, there are still a many of plants that have an anticancer potential but they have not yet been fully investigated (Cragg, 2005) ${ }^{[2]}$. Thus, the other solution for the harmful effects of synthetic drugs is the use of complementary alternative medicines as very few studies have been reported on the use of herbal medicine in management of prostate cancer (Rao et al., 2004) ${ }^{[13]}$

In the current investigation carried out, a screening of hydro alcoholic extracts of Momordica charantia leaves extracts were investigated for anticancer activity against breast cancer cell 
lines MCF 7 and HeLa human prostate cancer cell lines.

\section{Materials and Methods \\ Plant collection}

Momordica charantia plant was collected from surroundings of university the in November 2017. The plant was identified and authenticated. Fresh plant material was washed with water, air dried, and then blended to a fine powder. The powder was stored in airtight containers at $4^{\circ} \mathrm{c}$ for further use.

\section{Extraction}

About 150gms of fresh leaves were powdered and subjected to extraction by cold extraction. The extraction was done with methanol and acetone solvents. All the extracts were concentrated by a rotary vacuum evaporator and the leftover solvent was evaporated to dryness using a water bath. The phytochemical analysis was carried out by Elgorashi and Staden (2004) ${ }^{[5]}$ and Trease and Evans (2002) ${ }^{[17]}$.

\section{Antibacterial activity}

The antimicrobial activity of synthesized silver nanoparticles was investigated applying the standard agar well diffusion assay Nanda and Saravanan (2009). The tested pathogens were speeded uniformly on nutrient agar plates using sterile spreader, then, five wells of 6-mm diameter $(\mathrm{dm})$ were made using sterile well borer. Twenty micro litres of plant extracts with various concentrations $(25,50,75$, and $100 \mu \mathrm{g} / \mathrm{ml})$ was poured into the all wells. The plates were incubated at $37^{\circ} \mathrm{C}$ for $18 \mathrm{~h}$ for the bacterial after incubation the zone of inhibition were recorded.

\section{Anticancer activity \\ Cell culture}

Estrogen receptor (ER)-positive cancer cells were studied in this study. The cells were cultured in DMEM- Dulbecco's Minimum Essential Medium with 10\% FBS-fetal bovine serum and $50 \mathrm{~g} / \mathrm{mL}$ gentamicin. The cells were incubated at $37{ }^{\circ} \mathrm{C}$ in $\mathrm{CO}_{2}$ incubator in an atmosphere of humidified $5 \%$ $\mathrm{CO}_{2}$ and $95 \%$ air. The cancer cells growing in the exponential phase were used for cell viability assay.

Table1: Showing the phytochemicals present in the Momordica charantia leaves extracts.

\begin{tabular}{|c|c|c|}
\hline Tests & Methanol Extract & Acetone Extract \\
\hline Alkaloid & ++ & ++ \\
\hline Glycoside & + & + \\
\hline Steroid & + & ++ \\
\hline Flavonoid & - & + \\
\hline Saponin & ++ & ++ \\
\hline Reducing sugars & - & - \\
\hline Tannin & ++ & + \\
\hline
\end{tabular}

\section{Cell viability by MIT assay}

After $72 \mathrm{~h}$, the media of treated cells $(100 \mu \mathrm{L})$, were detached and the cell culture were incubated with $50 \mu \mathrm{L}$ of MTT at $37{ }^{\circ} \mathrm{C}$ for $4 \mathrm{~h}$ period. After incubation, the formazan produced was then solubilized by the addition of $100 \mu \mathrm{L}$ dimethyl sulfoxide. The suspension was placed on a microvibrator for $5 \mathrm{~min}$ and then the absorbance was recorded at $540 \mathrm{~nm}$ by an ELISA-Enzyme-linked immunosorbent assay reader and the results were analyzed in triplicate and the percentage was calculated (Mosmann 1983).

\section{Results and Discussion}

Plants are the most important source for all kind of food and medicine. From ancient time to modern world it is not possible to manufacture the medicine without plant or it's photochemical. They are valuable source of natural active constituents that are used to maintain human health and also used for the treatment of many human diseases (Stary and Hans, 1998) ${ }^{[15]}$. The use of medicinal plants for using in diseases treatment is as old as the human species. Accepted clarification on the use and effectiveness of medicinal plants considerably contribute to the disclosure of their medicinal properties, so that they are regularly prescribed, even if their phytochemical constituents are not always completely known (Silva et al., 2010) ${ }^{[14]}$. The phytochemical result tabulated in Table1 was found to be Alkaloid, Glycoside, Steroid, Flavonoid, Saponin, reducing sugars and Tannin for all the extracts. The result showed that all extracts contained appreciable amount of flavonoids and reducing sugars which was absent in both methanol and acetone extracts. (Sood et al. 2012) ${ }^{[15]}$ reports that phytochemical analysis of the plant confirm the presence of various phytochemicals like cardiac glycosides, tannins, carbohydrates, terpenoides, saponins resins, and phytosterols. While other phytochemical like alkaloids, glycosides, flavonoids, steroidal terpenes and phylobatamins were found to be absent in all the extracts.

Plant inferred specialists are being utilized for the treatment of disease. A few anticancer specialists from plants include; vinblastine, taxol, vincristine, the camptothecin derivatives, topotecan and etoposide, and etoposide got from epipodophyllotoxin are in clinical utilize everywhere throughout the world. Various malignancy research studies about have been led utilizing customary restorative plants with an end goal to find new remedial operators that do not have the poisonous symptoms related with current chemotherapeutic specialists and the medications under clinical phytomedicines has expanded significantly over the most recent two decades. Momordica charantia leaves extracts were experimented to estimate their antibacterial capacity against pathogenic bacteria like two strains of Gram +ve bacteria and Gram -ve bacteria like Klebsiella pneumoniae, Streptococcus pneumoniae Staphylococcus aureus and Escherichia coli using well diffusion method. Evaluation of antibacterial activity of these Momordica charantia extracts was shown in Table2 and Figure1. The results were shown that the extracts were potentially powerful in inhibiting the microbial growth of pathogenic bacteria.

Table2: Showing the Antibacterial activity of Momordica charantia leaves extracts

\begin{tabular}{|c|c|c|c|c|c|}
\hline \multirow{2}{*}{ Organisms } & \multicolumn{6}{|c|}{ Methanol Extract (MCME) } \\
\cline { 2 - 6 } & $\mathbf{1 0} \boldsymbol{\mu g}$ & $\mathbf{2 5} \boldsymbol{\mu g}$ & $\mathbf{5 0} \boldsymbol{\mu g}$ & $\mathbf{7 5} \boldsymbol{\mu g}$ & $\mathbf{1 0 0} \boldsymbol{\mu g}$ \\
\hline Klebsiella pneumoniae & 09 & 11 & 14 & 15 & 18 \\
\hline Streptococcus pneumoniae & 08 & 10 & 13.5 & 16 & 20 \\
\hline Staphylococcus aureus & 10 & 11 & 14 & 17 & 20 \\
\hline Escherichia coli & 11 & 11 & 14 & 15 & 19 \\
\hline B.cereus & 02 & 11 & 13 & 16 & 16 \\
\hline P.aeruginosa & 0 & - & - & - & - \\
\hline
\end{tabular}



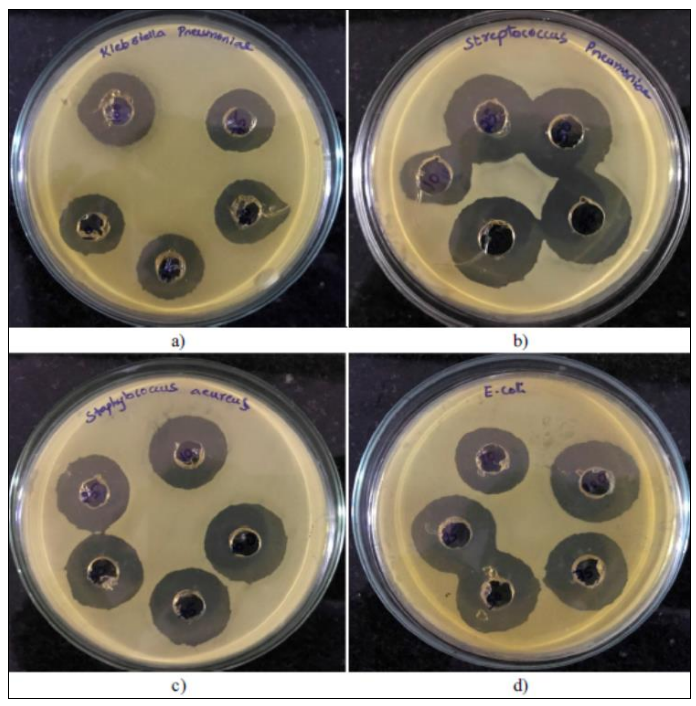

Fig 1: Antibacterial activity Klebsiella pneumoniae, Streptococcus pneumoniae Staphylococcus aureus and Escherichia coli.

In the present study Momordica charantia leaves were initially selected and tested for anticancer activity. The results on cytotoxicity of Momordica charantia leaves extracts on MCF 7 and HeLa cancer cell lines are shown in Table3.

Table3: Antiproliferative activity on human cells of fractions obtained from the Momordica charantia methanol- MCME and Acetone extract -MCAE.

\begin{tabular}{|c|c|c|}
\hline \multirow{2}{*}{ Test Extract } & \multicolumn{2}{|c|}{$\begin{array}{c}\text { Antiproliferative activity on Cell lines } \\
\text { (IC50) }\end{array}$} \\
\cline { 2 - 3 } & MCF7 & HeLa \\
\hline $\begin{array}{c}\text { Methanol extract } \\
\text { (MCME) }\end{array}$ & $15.6 \pm 1.3$ & $28.2 \pm 1$. \\
\hline $\begin{array}{c}\text { Acetone extract } \\
\text { (MCAE) }\end{array}$ & $174.2 \pm 1.3$ & $96.6 \pm 1.3$ \\
\hline
\end{tabular}

The evaluation of the anticancer activity of plant extracts is essential for safe treatment. It enables identification of the intrinsic toxicity of the plant and the effects of acute overdose (Padmaja et al., 2002; Rahman et al., 2016) ${ }^{[10,12] .}$ Cancerous cell lines were estimated by MTT assay. The methanol and acetone extract leaves of Momordica charantia has shown anticancer activity on selected cancer cell lines. Among the tested extracts, methanolic extract was found to have potent cytotoxicity against cancerous cell lines with MCF7 values ranging IC5015.6 \pm 1.3 (Figure2).
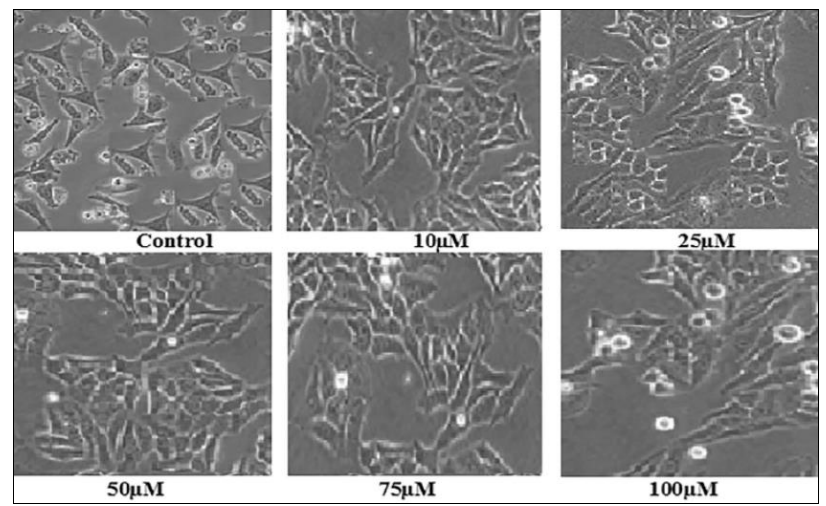

Fig 2: Antiproliferative activity on human cells of fractions obtained from the Momordica charantia methanol- MCME
The aromatic plants are a rich source of compounds with anticancer properties and deliver less harmfulness in normal cells. In this way, expanding consideration has been put on recognizing novel anticancer medication medicines from regular sources (Mukherjee et al., 2001; Wang et al., 2010; Desai et al., 2008) ${ }^{[8,3,19]}$. Most against tumour drugs are proposed to dispose of rapidly multiplying dangerous cells, and along these lines, they commonly show cytotoxicity and actuate apoptosis in disease cells (Kaufmann and Earnshaw, 2000). Apoptosis is an outstandingly composed cell death procedure described by loss of plasma layer phospholipid asymmetry, enzymatic cleavage of the DNA into oligonucleosomal sections, and division of the cells into film bound apoptotic bodies (Cotter, 2009). The present examination additionally explored the induction of apoptosis in breast tumour cells upon treatment with ethanolic concentrates of WS and TC Acridine orangeethidium bromide assay and Hoechst 33,342 assay by fluorescent microscopy revealed that the ethanolic extracts of WS and TC instigated apoptosis, but not necrosis, in breast cancer cells. DNA fragmentation is a hall mark property of apoptosis (Bortner et al., 1995) and DNA fragmentation assay further corroborated the ethanolic extracts of WS and TC induced apoptosis in breast cancer cells.

Apoptosis is the procedure of induction of altered cell death, and any variations in the normal in the typical pathways ensnared in apoptosis prompts minimal apoptosis and the protection toapoptosis initiates enhanced cell progression, which is ensnared in advancing disease (Kerr et al., 1972) [7]. During the induction of apoptosis, the cancer cells are subjected to beginning of events that include changes in both morphological and biochemical characteristics of the cell (Raff, 1992) ${ }^{[11]}$.

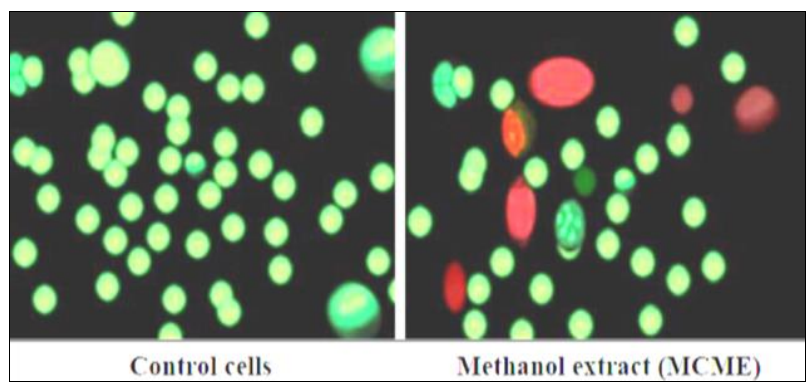

Fig 3: AO/EtBr staining of the MCF-7 cells. (a) Control - viable cells shows green stained nuclei. (b) Extract treated MCF-7 cells showing the red colour seems dead cells.

In the present investigational study, both normal and breast cancer cells were subjected for the examination of morphological changes incited by Momordica charantia methanol extract separate (MCME) A major change in the cell morphology was observed in the breast cancer cells with cell shrinkage, cell wall blebbing and reduction in cell population in Momordica charantia methanol extract (MCME) treated cells contrasted to the untreated cells Figure3.

There were no such critical alterations seen in the Momordica charantia methanol extract (MCME) treated normal cells which indicated the nontoxic nature of the compound toward the normal breast cell lines. Most anticancer compounds or drugs are projected to remove quickly proliferating malignant cells, and therefore, they typically 
indicate cytotoxicity and induce apoptosis in cancer cells (Kaufmann \& Earnshaw, 2000). Apoptosis is a especially formed cell death process characterized by loss of plasma membrane phospholipid asymmetry, enzymatic cleavage of the DNA into oligonucleosomal fragments, and segmentation of the tumour cells into membrane-bound apoptotic bodies (Cotter, 2009). The present study also examined the induction of apoptosis in breast cancer cells upon treatment with Methanolic extracts (MCME). Acridine orange-ethidium bromide experiment and Hoechst 33,342 assay by fluorescent microscopy revealed that the Methanolic extracts of (MCME) instigated apoptosis, but not necrosis, in human breast tumour cells. DNA fragmentation is a trait property of apoptosis (Bortner et al., 1995).

\section{Conclusion}

Plants play a vital role in health care applications with about $80 \%$ of the world's populations depending on the use of conventional medicine which is primarily based on plants. In the present study the phytochemical characterization, Antibacterial and anticancer studies of the extract were shown remarkable results thus the identification of liable bioactive compounds and quality standards are necessary for future study.

\section{References}

1. American Cancer Society. Global Cancer Facts and Figures, 2011.

2. Cragg GM, Newman DJ. Plants as a source of anticancer agents. J. Ethno-pharmacol 2005;100:72-79.

3. Desai AG, Qazi GN, Ganju RK, El-Tamer M, Singh J, Saxena AK et al. Medicinal plants and cancer chemoprevention. Curr. Drug Metab 2008;9:581-591.

4. Douglas Hanahan, Robert A. 2000;Cell100:57-70.

5. Elgorashi EE, van Staden JJ. Pharmacological screening of six Amaryllidaceae species. Ethnopharmacol 2004;90:27-32.

6. Fimognari C, Lenzi M, Ferruzzi L, Turrini E, Scartezzini P, Poli F. Mitochondrial pathway mediates the antileukemic effects of Hemidesmus indicus, a promising botanical drug. PLoS One 2011;6:21544.

7. Kerr JF, Wyllie AH, Currie AR. Apoptosis: a basic biological phenomenon with wide-ranging implications in tissue kinetics. Br. J. Cancer 1972;26:239-257. Back to cited text no. 24.

8. Mukherjee AK, Basu S, Sarkar N, Ghosh AC. Advances in cancer therapy with plant based natural products. Curr. Med. Chem 2001;8:1467-1486.

9. Newman DJ, Cragg GM, Snader KM. Natural products as sources of new drugs over the period. J Nat. Prod. 2003;66:1022-1037.

10. Padmaja R, Arun PC, Prashanth D, Deepak M, Amit A, Anjana M. Brine shrimp lethality bioassay of selected Indian medicinal plants. Fitoterapia 2002;73:508-510.

11. Raff MC. Social controls on cell survival and cell death. Nature 1992;356:397.

12. Rahman MA, Akhtar J, Arshad M. Evaluation of cytotoxic potential and apoptotic effect of a methanolic extract of Bauhinia racemosa Lam. against a human cancer cell line, HeLa. Eur. J. Integrative Med 2016;8:513-518.

13. Rao KVK, Schwartz SA, Nair HK, Aalinkeel R, Mahajan S, Chawda R. Plant derived products as a source of cellular growth inhibitory phytochemicals on PC-3M, DU-145 and LNCaP prostate cancer cell lines. Curr. Sci 2004, 1585-1588.

14. Silva NCC, Fernandes Júnior A. Biological properties of medicinal plants: a review of their antimicrobial activity. J. Venomous Anim. Toxins Incl. Trop. Dis. 2010;16:402-413.

15. Sood A, Kaur P, Gupta R. Phytochemical screening and antimicrobial assay of various seeds extract of Cucurbitaceae family. Stary, F., Hans, S., 1998. The National Guides to Medical Herbs and Plants. Tiger Books Int. Plc., UK, 2012.

16. Tanih NF, Ndip RN. The acetone extract of Sclerocaryabirrea (Anacardiaceae) possesses antiproliferative and apoptotic potential against human breast cancer cell lines (MCF-7). Scientific World J 2013.

17. Trease G, Evans SM. Pharmacognosy. Bailer Tindal, London, 2002, 23-67.

18. Verpoorte R. Pharmacognosy in the new millennium: lead finding and biotechnology. J Pharm. Pharmacol 2000;52:253-262.

19. Wang S, Penchala S, Prabhu S, Wang J, Huang Y. Molecular basis of traditional Chinese medicine in cancer chemoprevention. Curr. Drug Discov. Technol 2010;7:67-75.

20. World Health Organisation (WHO). Cancer, 2013. 